\title{
Does Accounting Conservatism Still Exist in Disruptive Era? The Mars Approach
}

\author{
Avi Sunani ${ }^{1}$, Rony Wardhana ${ }^{2}$, Putri Zanufa Sari ${ }^{3}$, Ariyani $^{4}$, Rudi Harianto ${ }^{5}$ \\ \{avisunani@narotama.ac.id ${ }^{1}$, rony.wardhana@narotama.ac.id ${ }^{2}$, putrizanufa@ narotama.ac.id ${ }^{3}$ \} \\ University of Narotama, Jl. Arif Rahman Hakim No.51, Klampis Ngasem, Sukolilo, Kota SBY, Jawa \\ Timur $60117^{123}$
}

\begin{abstract}
Conservatism is a principle which affects valuation in accounting because conservative still has an important role in accounting practices. The purpose of this study was to analyze the influence of the financial distress, managerial ownership structure, growth opportunities, and debt covenant on accounting conservatism in Indonesia companies that use multimedia. Purposive sampling method was used to determine the sample, which generates 113 companies. Multiple linear regression and Multivariate Adaptive Regression Spline (MARS) was used to analyze the data. The result of the normality test showed that residual was not normally distributed. Consequently, MARS was used to analyze the data. Result of the study suggested that financial distress, managerial ownership structure, growth opportunities, and debt covenant have an effect on accounting conservatism. Moreover, managerial ownership structure has the most effect on accounting conservatism. Therefore, management should pay attention in making policies in order to increase the firm value and investor intention to invest their capital.
\end{abstract}

Keywords: accounting conservatism, debt covenant, financial distress, growth opportunities, managerial ownership structure

\section{Introduction}

Conservatism is the principle in financial reporting, which is intended to recognize and measure assets and profits with due care because economic and business activities are surrounded by uncertainty. The implication of applying this principle is in the choice of accounting method that reports lower profits and assets or higher debt. The principle of conservatism will generate profits and assets that tend to be low, and costs and debts tend to be high. This trend occurs because conservatism adheres to the principle of slowing down revenue recognition and accelerating the recognition of expenses.

Conservatism is a principle that can affect valuation in accounting. In addition, the application of conservatism will generate quality profits because the principle of conservatism prevents companies from exaggerating profits and helps users of financial statements by presenting non-overstate earnings and assets [1]. The concept of accounting conservatism is still a pro-contra and debate to date. Previous research has also analyzed a lot of accounting conservatism and suggested different findings related to the level of financial difficulties, managerial ownership structure, growth opportunities, and debt covenants. Thus, researchers are motivated to conduct an accounting conservatism research using analytical methods that are different from previous studies, namely Multivariate Adaptive Regression Spline (MARS). 


\section{Literature Review and Hypotheses Development}

\subsection{Signaling Theory}

Signal theory explains how companies can provide a signal to users of financial statements, and the signal is in the form of information about what has been done by management[2]. The other researcher argues that the signal is an action taken by the management of the company to give instructions to investors about how management views the prospects of the company[3]. The selection of conservative accounting policies signals the managers' confidence in the company in the future[3]. For investors, the information conveyed by management regarding the company's goals can influence market investment decisions because the information is very important for investors and business people in decision making.

The relationship between signaling theory and the variables in this study is that if the level of the company's financial difficulties is lower, it shows a positive signal for a creditor because the lower the level of financial difficulty indicates the condition of the company's financial condition is not a problem. The managerial ownership structure of the company shows higher negative signals for creditors because managers tend to report low profits that harm creditors. Growth opportunities companies increasingly show a negative signal for creditors because the higher the chance of growth of the company, the greater the funds needed. The company's debt covenant shows a higher positive signal for creditors because the higher the debt agreement, the creditor becomes safer to reduce the ability to violate the debt contract.

\subsection{Positive Accounting Theory}

Positive accounting theory explains that managers have incentives or incentives to be able to maximize their welfare. This theory also explains things that encourage management to choose the optimal accounting method to achieve certain goals. Positive accounting theory is related to the possibility of actions taken by managers in choosing accounting policies and how managers react to new accounting policy proposals[3]. Positive accounting theory predicts that managers tend to increase earnings to hide poor performance. The tendency to increase profits made by managers can be driven by the existence of four contracting problems, namely asymmetric information, limited working period of managers, limited manager's obligations, and payment asymmetry. Positive accounting theory predictions were grouped into three hypotheses, namely: bonus plan hypothesis, debt covenant hypothesis, and size hyphotesis[3].

The relationship of positive accounting theory with this research is that if the level of corporate financial difficulties is higher, it shows negative accounting theory for a manager because the higher the level of financial difficulties shows the poor quality of the manager. The managerial ownership structure of the company shows a higher positive accounting theory for a manager because of management as a shareholder. Growth opportunities companies increasingly show a positive signal of accounting theory for managers so that financing for investment can be fulfilled. Debt covenant shows higher positive accounting theory for a manager because the manager will obtain additional funds from the creditor.

Based on the statement of signaling theory, managers raise the level of accounting conservatism if the company's finances are problematic. Conservatism is the principle of caution so that with financial difficulties, companies will be more careful in facing uncertain environments. Thus, the higher level of financial difficulties of financial companies will encourage managers to raise the level of accounting conservatism, and vice versa if the level of low financial difficulties of managers will reduce the level of accounting conservatism [4], and 
another study concluded that the level of financial difficulties has an effect on accounting conservatism[5].

\section{H1 The level of financial difficulties has an effect on accounting conservatism}

The ownership structure is an internal factor in the company to determine the progress of the company. The motivation of a manager is no longer to get a high bonus with increasing profits but because of the feeling of having a manager for the company. It assumes that the greater managerial ownership proxied by the percentage of company stock ownership, the managerial will be more concerned with the percentage of ownership so that the policies taken by the manager will be more conservative. The opposite applies if managerial ownership is low against the company so managers tend to be less conservative and tend to report higher profits because it will bring benefits to managers received through commissions according to the number of profits. Some studies found that managerial ownership structures influence accounting conservatism[6][7].

\section{H2: Managerial ownership structure has an effect on accounting conservatism.}

Growth opportunities are opportunities for companies to invest in profitable things. Companies to grow and develop certainly need opportunities. Competition in the business world is also a challenge that requires companies to develop. The company increases investment, so there are no actions that damage the company's finances. The number of funds needed by the company will cause managers to apply the principle of accounting conservatism so that financing for investment can be fulfilled. Companies that have high growth rates are motivated to minimize profits. The higher the growth rate of the company, the higher the possibility of companies to choose accounting that is conservative. Growth opportunities have an effect on accounting conservatism[8].

\section{H3: Growth opportunities have an effect on accounting conservatism}

Debt covenant has a role in conservatism in two ways. First, bondholders can explicitly use accounting conservatism. Second, managers can implicitly use accounting conservatism consistently in order to build a reputation for conservative financial reporting. The motive for selecting an accounting method is inseparable from positive accounting theory, one of which is the debt covenant hypothesis. The debt covenant hypothesis states that when a company begins to approach a violation of a debt agreement, the company manager will try to avoid the occurrence of the debt agreement by choosing accounting methods that can increase profits. The greater the level of debt covenant of a company, the lower the level of corporate conservatism. The other study found that debt covenant has an effect on accounting conservatism[9].

\section{H4: Debt covenant has an effect on accounting conservatism.}

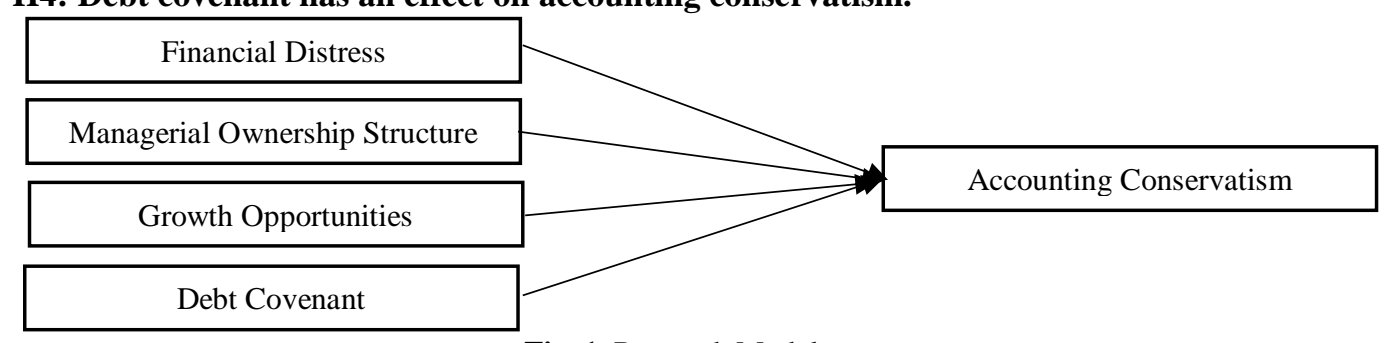

Fig. 1. Research Model 


\section{Research Methodology}

The population of this research is the manufacturing companies that use multimedia from 2013 to 2015 . Sample of this study was determined by purposive sampling method. The criteria of the sample were: (1) Manufacturing companies listed on the Indonesia Stock Exchange in 2013-2015. (2) Publish financial statements consecutively in 2013-2015. (3) Publish financial statements as of December 31. (4) Having complete data in accordance with the required variables. The data used in this study are secondary data obtained from the company's financial statements through the official website of the Indonesia Stock Exchange (www.idx.co.id). Multiple Linear Regression and Multivariate Adaptive Regression Spline (MARS) were used to analyze the data.

\section{Result and Analysis}

\subsection{Multiple Linear Regression}

Multiple linear regression is a parametric regression. Parametric requirements are expected to be fulfilled, namely, residuals follow a normal distribution, no residual autocorrelation occurs, residual heteroscedasticity does not occur, and between independent variables, there is no case of multicollinearity. This classic assumption is to test the goodness of fit model. If all parametric requirements are met so that the model is good or known as BLUE (Best Linear Unbias Estimation)

\subsection{Normality Test}

Normality test is to test the normality of the residual regression performed using the Kolmogorov-Smirnov test. The regression model has normally distributed if the KolmogorovSmirnov statistic of the residual value has a significance value of $\alpha=0.05$. The results of the normality test show that the significance value $=0.00$ <alpha $(0.05)$. It can be concluded that the residuals in this study are not normally distributed. Consequently, the data should be analysed use MARS approach.

\subsection{Multivariate Adaptive Regression Spline (MARS)}

MARS is nonparametric regression analysis, so those parametric requirements are not applied to this method. One of the supporting factors for conducting the effect test is the MARS method by looking at each plot matrix of the independent variable on the dependent variable. The plot matrix of the independent variables on the dependent variable is as follows: 


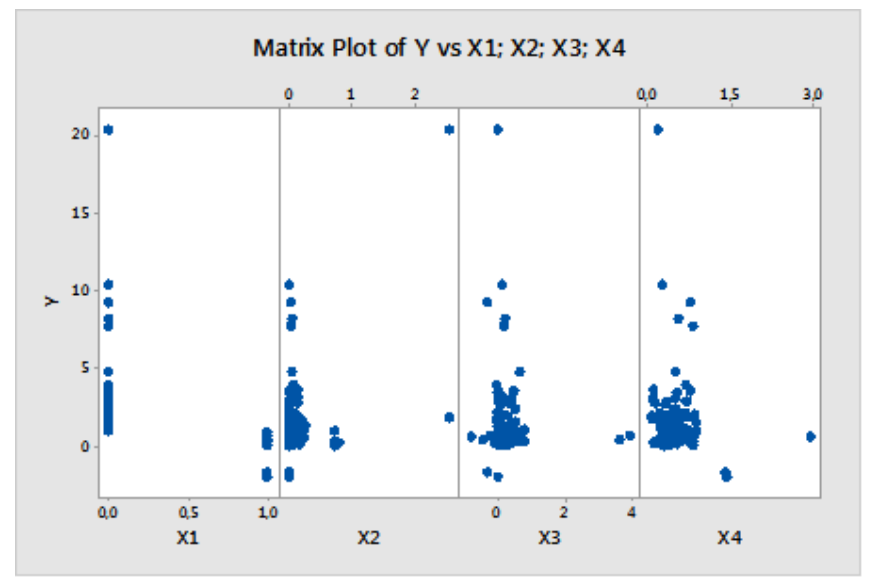

Fig. 2. Matrix Plot

From the results of the ICR, MWON, GROWTH, DAR, and MTBR variables plots of MTBR indicate that the tendency of plots does not show a tendency to form a certain pattern. With the limited information about the shape of the function and the unclear patterns of the relationship between the response variable and the predictor, it is a consideration to use nonparametric regression to model the data. The nonparametric regression approach used in this study was multivariate adaptive regression spline (MARS), one of the most accurate nonparametric models.

The formation stage of the MARS model is carried out by a combination of the maximum number of Base Functions (BF), Maximum Interactions (MI) and Minimum Observations (MO) between knots until the optimal model is obtained with minimum GCV. The base function (BF) used is $2 x, 3 x$, and $4 x$ the number of predictor variables. Another study recommends choosing the maximum number of basic functions of two to four times the number of predictor variables[10]. The maximum interaction (MI) used in this study is 1,2 , and 3. Because if there are more than three interactions, it will lead to a very complex interpretation of the model. For the minimum observation (MO) used is $5,10,20$ so that at these points, the minimum GCV value is obtained [10]. Determine the best model of the combination of BF, MI, and MO values that are possible with minimum GCV value criteria and parameter estimation. The best selection model criteria are to compare the minimum GCV if it has the same value, it can be seen by considering the smallest MSE value.

In testing the analysis of accounting conservatism with the MARS method, the best model with the smallest $\mathrm{GCV}$ was obtained on the combination of $\mathrm{BF}=16, \mathrm{MI}=3$ and $\mathrm{MO}=0$ with $\mathrm{GCV}=2.6600$ and $\mathrm{MSE}=1.8630$. The results of the combination of BF, MI and MO are presented in Table 1 
Table 1. The combination of BF, MI, and MO

\begin{tabular}{ccccccccccccccc}
\hline BF & MI & MO & MSE & GCV & BF & MI & MO & MSE & GCV & BF & MI & MO & MSE & GCV \\
\hline & 1 & 0 & 3,9070 & 4,2680 & & 1 & 0 & 3,9070 & 4,3220 & & 1 & 0 & 2,9070 & 4,3220 \\
& 1 & 5 & 3,9070 & 4,2680 & & 1 & 5 & 3,9070 & 4,3220 & & 1 & 5 & 3,9070 & 4,3220 \\
& 1 & 10 & 3,9580 & 4,3790 & & 1 & 10 & 3,9580 & 4,3790 & & 1 & 10 & 3,9580 & 4,3790 \\
& 1 & 20 & 4,0420 & 4,4720 & & 1 & 20 & 4,0420 & 4,4720 & & 1 & 20 & 4,0420 & 4,4720 \\
& 2 & 0 & 2,5690 & 2,8570 & & 2 & 0 & 2,5690 & 2,8850 & & 2 & 0 & 2,5690 & 2,9010 \\
8 & 2 & 5 & 2,5690 & 2,8570 & & 2 & 5 & 2,5690 & 2,8850 & & 2 & 5 & 2,5690 & 2,8960 \\
& 2 & 10 & 2,9870 & 3,4970 & & 2 & 10 & 3,2810 & 3,6850 & & 2 & 10 & 2,8900 & 3,6300 \\
& 2 & 20 & 2,9700 & 3,5650 & & 2 & 20 & 2,9700 & 3,5930 & & 2 & 20 & 2,9700 & 3,6030 \\
& 3 & 0 & 2,5690 & 2,8570 & & 3 & 0 & 2,1820 & 2,9410 & & 3 & 0 & 1,8630 & 2,6600 \\
& 3 & 5 & 2,5690 & 2,8570 & & 3 & 5 & 2,1820 & 2,8330 & & 3 & 5 & 2,5690 & 2,8810 \\
& 3 & 10 & 2,9870 & 3,4970 & & 3 & 10 & 3,2810 & 3,6850 & & 3 & 10 & 3,1020 & 3,6770 \\
& 3 & 20 & 2,9700 & 3,5650 & & 3 & 20 & 2,9700 & 3,5990 & & 3 & 20 & 2,3110 & 3,7500 \\
\hline
\end{tabular}

In testing the accounting conservatism analysis shows that the value of Fcount $=46,249>\mathrm{f}$ $(0.05 ; 6 ; 106)=2.185$ with the R-square value $=0.708$. This shows that the MARS method is able to explain the response variable well and the variability of the level of financial difficulty (X1), managerial ownership structure (X2), growth opportunities (X3), debt covenant (X4) to the analysis of accounting conservatism of $96.8 \%$. Hypothesis test results show that the level of financial difficulty (X1), managerial ownership structure (X2), growth opportunities (X3), debt covenant (X4) is included in the important variable. This is suggested that the level of financial difficulty (X1), managerial ownership structure (X2), growth opportunities (X3), debt covenant (X4) influences the analysis of accounting conservatism. In the importance table, the highest importance of managerial ownership structure (X2) with a value of -GCV is 6.437. This shows that the most influential variable on the analysis of accounting conservatism is the managerial ownership structure (X2).

\section{Discussion}

The level of financial difficulties can affect the level of accounting conservatism. The influence of the level of financial difficulty due to the financial condition of a company depends on how the manager overcomes the problems that occur in the company. The higher the level of financial difficulties, the higher the intensity of the conflict of interest within it. Managers are encouraged to present financial statements that can accommodate the interests of users of financial statements, namely investors and creditors. Managers set the level of conservatism of the company to generate good financial statements.

The level of financial difficulties influences the level of accounting conservatism. These results support the signaling theory, which states that the level of financial difficulty is influential, and also supports positive accounting theory, which states that the level of financial difficulties influences accounting conservatism. Positive accounting theory predicts that managers will tend to increase profits to hide poor performance. The financial condition of the company is problematic because of the poor quality of the manager. This makes shareholders 
reimburse managers and result in a decrease in the market value of managers in the labor market and can encourage managers to reduce the level of accounting conservatism.

Companies that do not have financial problems will apply conservative accounting to avoid possible conflicts with creditors and shareholders. Therefore, the higher level of financial difficulties will encourage managers to reduce the level of accounting conservatism and if a low level of financial difficulty will encourage managers to raise the level of accounting conservatism. Based on these results, the first hypothesis of the study which predicts the level of financial difficulties affects accounting conservatism is proven to be true, the higher the level of financial difficulties will further reduce the level of accounting conservatism. This result is in line with the results of previous studies by [4] and [5].

Managerial share ownership (board of commissioners and directors) is one of the company's internal factors that determine the company's progress. One way that can be done to harmonize the interests of owners and management is by involving management in a fairly large shareholding structure. The higher managerial ownership structure may not necessarily increase accounting conservatism. Based on the results of the study, the second hypothesis assumes that managerial ownership structures have an influence on accounting conservatism proven to be true. Managerial ownership structure supports positive accounting theory. Managers have incentives to be able to maximize their welfare because, in the ownership structure, the manager is also a shareholder in the company. Decision making and activities that occur in companies with managerial ownership are certainly different from companies without managerial ownership. This result is consistent with the assumption that ownership by managerial parties can also act as a supervisory function in the financial reporting process because any changes that occur in the managerial ownership structure affect accounting conservatism. These results support previous studies conducted by [6] and [7].

Growth opportunities are opportunities for companies to invest in profitable things. The challenge for managers is to balance the income and use of debt needed by the company. The higher the growth opportunities, it will not necessarily increase accounting conservatism. Based on these results, the third hypothesis of the study, which suspected that growth opportunities influenced accounting conservatism proved to be true. These results support previous research by $[8]$.

Based on the results of the study, the fourth hypothesis of the study, which suspected that debt covenants influenced accounting conservatism proved to be true. This is in line with the results of [9]. The higher the debt covenant it will increase accounting conservatism. Debt covenant supports positive accounting theory when the company begins to approach the occurrence of violations of the debt agreement, the company manager will try to avoid the occurrence of debt agreements by choosing accounting methods that can increase profits. Violations of debt agreements can result in a cost and hamper management's work so that they will try to prevent or delay. Long-term debt contracts are agreements to protect lenders from the actions of managers against creditors, this contract is based on positive accounting theory, namely the debt covenant hypothesis. This hypothesis predicts that managerial wants to increase profits and assets to reduce the cost of negotiating debt contracts when the company decides on its debt agreement. The closer the company is to violating the debt agreement, the manager will tend to choose accounting procedures that can move earnings for the next period to the current period so that accounting conservatism will increase. 


\section{Conclusion, Limitation, and Future Work}

This study suggested that the level of financial difficulties, managerial ownership structure, growth opportunities, and debt covenants influence accounting conservatism in manufacturing companies that use multimedia. This study has limitations, namely, the level of accounting conservatism in the manufacturing companies is measured by the market to book ratio approach, and the stock price used in the measurement of this study does not distinguish common shares or preferred shares. Therefore, it is suggested that further research can measure the level of accounting conservatism by using other approaches such as market capital, operating profit approach, cash flow accrual approach, or non operating accruals.

\section{References}

[1] D. Y. A. S. Fala, "Pengaruh Konservatisme Akuntansi Terhadap Penilaian Ekuitas Perusahaan Dimoderisasi oleh Good Corporate Governance," in Simposium Nasional Akuntansi X, 1-23 Unhas Makassar 25-28 Juli 2007, 2007, pp. 1-23.

[2] I. . Wolk, G. . Thearny, and L. . Dodd, Accounting Theory: A Conceptual and Institusional Approach, Fifth edit. Ohio: South-Western College Publishing, 2001.

[3] R. . Scott, Financial accounting theory. Sixth Edition. Canada: Pearson Education Canada.

[4] H. Kao and P. Sie, "Accounting Conservatism Trends and Financial Distress : Considering the Endogeneity of the C-Score,” Int. J. Financ. Res., vol. 7, no. 4, pp. 149-167, 2016.

[5] E. Suryandari and R. E. Priyanto, "Pengaruh Risiko Litigasi dan Tingkat Kesulitan Keuangan Perusahaan terhadap Hubungan antara Konflik Kepentingan dan Konservatisme Akuntansi," J. Akunt. dan Investasi, vol. 12, no. 2, pp. 161-174, 2012.

[6] D. P. Brilianti, "Faktor-faktor yang Mempengaruhi penerapan Konservatisme Akuntansi Perusahaan,” Account. Anal. J., vol. 2, no. 3, pp. 268-275, 2013.

[7] A. Septian and Y. D. Anna, "Pengaruh Kepemilikan Manajerial, Ukuran Perusahaan, Debt Covenant, Dan Growth Opportunities Terhadap Konservatisme Akuntansi (Studi pada sektor Industri Farmasi yang Terdaftar di Bursa Efek Indonesia Tahun 2008-2012)," in e-Proceeding of Management, 2014, vol. 1, no. 3, pp. 452-469.

[8] Agustina, Rice, and Stephen, "Akuntansi Konservatisme Pada Perusahaan Manufaktur yang Terdaftar di Bursa Efek Indonesia," J. Din. Akunt. dan Bisnis, vol. 3, no. 1, pp. 1-16, 2016.

[9] A. M. M. Hamdan, M. H. Abzakh, and M. H. Al-Ataibi, "Factors Influencing the Level of Accounting Conservatism in the Financial Statements," Int. Bus. Res. J., vol. 4, no. 3, pp. 145-155, 2011.

[10] J. . Friedman, "Multivariate Adaptive Regression Splines (with discussion). Annual Statistics $19, " 1991$. 